\title{
Do families shape corporate governance structures?
}

\author{
María SaCristán NaVARro \\ Department of Business Administration, Rey Juan Carlos University, Madrid, Spain
}

\section{Silvia GOMEZ ANSÓN}

Department of Business Administration, University of Oviedo, Oviedo, Spain

\section{ABSTRACT}

This paper provides empirical evidence of family firm corporate governance structures, by examining a set of corporate governance characteristics of 132 non-financial Spanish listed firms. Results show that family firm boards present differential characteristics and that different patterns of family ownership configurations do not affect family firm corporate governance structures. We find that Spanish family firm boards are smaller than those in non-family firms. Family firm directors own a larger fraction of firm shares and have longer Chairman tenure than non-family firms, and family firms use fewer voluntary board committees - such as nomination and remuneration committees and executive committees. Besides, family firm boards and committees are biased towards insiders. Whether these differential characteristics affect other minority non-family shareholders negatively remains an open question.*

Keywords: family firms, corporate governance, board composition, board committees

\section{INTRODUCTION}

In the USA, family ownership constitutes approximately $35 \%$ of large ${ }^{i}$ publicly traded firms (Anderson \& Reeb 2004; Villalonga \& Amit 2006); in East Asia, more than two-thirds of firms are controlled by a single shareholder managers of closely held firms frequently being relatives of the controlling shareholder family (Claessens et al. 2002); and in Western Europe, the majority of publicly held firms remain family controlled (Faccio \& Lang 2002).

Given the significant role family firms play in the global economy, gaining a better understand- ing of the factors that influence their management practices, corporate governance structures and performance is particularly important (Chrisman et al. 2006). Family influence on firm corporate governance structures and performance has been analyzed from different perspectives: agency theory (Fama \& Jensen 1983); resourcebased view (RBV) (Habbershon \& Williams 1999; Carney 2005, Le Breton-Miller \& Miller 2006); or stewardship theories (Davis et al. 1997; Sundaramurthy et al. 2003). In this paper we refer mainly to the agency theory.

Traditionally, agency theory assumes that

\footnotetext{
A previous version of this paper was presented at the Third Annual Workshop on Corporate Governance, 9-11 November 2006, held at the EIASM, Brussels. We acknowledge the participants' comments.

i Nevertheless we must take into account the effect of size. As Donkels and Frohlich's (1991) remark, for large firms family ownership may not be synonymous with family control whilst in smaller companies, ownership controlled by families is still a key characteristic.
} 
agency costs are not likely to occur in family businesses with a single shareholder, where the family also manages the firm (Fama \& Jensen 1983). However, as firms grow and go public, ownership structures may be a combination of family ownership and non-family ownership; thus agency costs may be incurred with divergence in interests between family and non-family shareholders. Consequently, from an agency point of view, family firm corporate governance structures become extremely important when other large shareholders and minority non-family shareholders coexist with family shareholders, which is the case for publicly listed family firms.

Family business corporate governance structures should adapt to this situation by establishing specific corporate governance structures that take into account the three systems model in order to govern family firm relations (Davis \& Taguiri 1989): the family, other firm shareholders, and managers. Moreover, although family firm corporate governance structures should reflect their idiosyncratic features, family firm corporate governance structures should ensure minority shareholder returns by restricting opportunistic behaviours by managers and families. Implementing good governance practices should in this sense be considered as a 'good family dynamic' (Martin de Holan \& Sanz 2006).

Recent literature suggests that corporate governance structures should better 'fit' family firm peculiarities (Corbetta et al. 2004; Lane et al. 2006; Voordeckers et al. 2007). Empirical analyses of family firm governance structures are needed to better understand family firm peculiarities. Most family firm governance studies have analysed the impact on firm performance of: who 'manages' the firms (by examining whether the firms are family or professionally-managed); who 'controls' the firms (by examining whether the firms have a family Chairman or not); and/or by differentiating between founders or descendants as either managers or directors (Anderson \& Reeb 2003; Barth et al. 2005; Jayaraman et al. 2000; Schulze et al. 2001; Sacristán \& Gómez
Ansón 2006; Sraer \& Thersmar 2004). A few papers from Anglo-Saxon countries (Anderson \& Reeb 2004; Bartholomeusz \& Tanewski 2006; Klein et al. 2005; Ricart et al. 1999; Villalonga \& Amit 2006), analyze other corporate governance variables, such as: board size, board composition, and board committees. The results of these studies shed some light on the idiosyncratic characteristics of family firm corporate governance structures. Villalonga and Amit (2006) show that family ownership creates value, only when the founder serves as the CEO of the firm or as its Chairperson. In Greece, Bartholomeusz and Tanewski (2006) conclude that family firms rely more on internal control mechanisms than nonfamily firms, while in Canada, Klein et al. (2005) suggest that family firms are apparently penalized for having independent boards.

Our paper aims to analyse to what extent family firm corporate governance structures differ from that of non-family firms and whether different family ownership configurations (i.e. use of pyramidal structures) affect family firm corporate governance structures. This study contributes to the corporate governance and family firm literature in several ways. First, the paper presents a comprehensive review of family firm corporate governance structures. Second, we present empirical evidence about the influence of family ownership on corporate governance structure in a Continental European country (Spain - where family controlled firms account for more than $50 \%$ of publicly listed firms, Sacristán \& Gómez 2007). Third, as family firm corporate governance studies consider that family firms are not all alike, we address whether different family ownership structures affect firm corporate governance structures, by analyzing whether family use of pyramidal structures determine differential corporate governance structures.

The results suggest that there are significant differences between family and non-family firm corporate governance structures, but that different family ownership configurations do not influence family firm corporate governance structures. The study shows that family firm cor- 
porate governance structures are characterised by insider family control.

Section 2 discusses the Spanish institutional setting and provides theoretical background on the relationship between family ownership and firm corporate governance structures. Section 3 presents the methodology and the variables of the study; section 4 describes the results of the analyses and section 5 presents conclusions and implications of the paper for researchers and practitioners.

\section{THEORETICAL BACKGROUND}

Corporate governance is related to legal protection of investors and to cultural traditions (La Porta et al. 1998, 1999; Ellul et al. 2006). According to Bukart et al. (2003), with low shareholder protection, the founder's ability to control expropriation from managers will be too limited, and therefore managers remain within the family even when someone else may run the firm more efficiently. This argument leads to a prediction of a negative relationship between investor protection and ownership concentration, consistent with empirical evidence (La Porta et al. 1998, 1999, 2000). The law and finance literature also helps explain why 'family firms' - in which the founder family is a shareholder or even the manager over several generations - are an enduring phenomenon in French civil law countries, as is the case of Spain. Spanish firms have a high family ownership concentration with a high incidence of family pyramidal structures (La Porta et al. 1997, 1998, 1999; Faccio \& Lang 2002; Sacristán \& Gómez Ansón 2007).

\subsection{Family firm corporate governance structures}

Shelifer and Vishny (1997) emphasize the importance of studying the characteristics of family firms in order to understand the economic efficiency of corporate governance mechanisms. As already pointed out, given their differential characteristics, family firm corporate governance structures should differ from non-family ones. These differences may not necessarily affect firm performance negatively.
The underlying logic of the traditional agency theory argument is that manager and shareholder interests may diverge and that the board is a mechanism for aligning those interests through the monitoring and the ratifying of managerial decisions (Hillman et al. 2000). The above description refers to the 'classical' agency problem (Type I agency problem, Villalonga \& Amit 2006). In family firms, families are the large shareholders and they may also appoint firm managers; thus, there may be not so many agency problems between managers and large shareholders, but another type of agency problems caused by the coexistence of minority and large shareholders (Morck \& Yeung 2003). When large shareholders are present, i.e. families or individuals, they may have an incentive to extract private benefits of control at the expense of minority shareholders (Type II agency problem, Villalonga \& Amit 2006). Specifically, in family firms, 'managerial entrenchment' may be caused by the pursuit of family interests.

Since family firm agency problems are different from those of widely held firms, one may also expect family firm corporate governance structures to be different. In family firms, the interests of managers and owners may be aligned and the corporate governance devices designed for widely held firms may prove inefficient in family businesses (Barney \& Hansen 1994; Jaskiewicz \& Klein 2007).

Corporate governance differences between family and non-family firms may actually relate to different characteristics of the board of directors. Lester and Cannella (2006) suggest that boards may serve more than the traditional governance function of counselling, evaluating and controlling company management. They perceive the board of directors as a resource used by family firm owners to assist family executives (less so than to monitor them) and to reduce within-family agency costs. In addition, family members - as large owners - will be less threatened by the market for corporate control and may be more keen to develop board interlocks. 


\section{Executive vs independent directors}

The board of directors is comprised of: inside (or executive) directors and outside directors (nominee directors, those representing large shareholders, and independent directors). For family firms, a CEO near retirement may add inside directors in order to facilitate his or her succession process (Hermalin \& Weisbach 1988) and a board dominated by insiders could facilitate transition in family firms and enhance firm performance. The results for Canada (Klein et al. 2005) support this prediction. Family firms seem to be penalised for having boards that are independent of company management. Moreover, outside directors may reduce the influence of the board due to their lack of knowledge about the firm and its environment. Consequently, family firm boards should be characterized by a balance between independence and interdependence (Corbetta et al. 2004). In any case, in family firms, family control may be exercised through different ways: by controlling the board of directors; and/or by assuming the members' executive functions. Accordingly, we propose the following hypothesis:

H1: Family firms will present a lower proportion of independent directors in favour of nominee and executive directors than nonfamily firms.

Other board characteristics - such as board size, duality, CEO or Chairman tenure, and the existence and composition of board committees may also affect the monitoring role of the board.

\section{Board size}

While there are arguments in favour of and opposed to small boards (Jensen 1993; Kose \& Lemma 1998; Rosenstein \& Wyatt 1990), empirical evidence indicates that smaller boards enhance firm performance (Yermack 1996; Eisenberg et al. 1998; Fernandez et al. 1998). For family firms, Lane et al. (2006) suggest that small boards may be more desirable, as larger boards may inhibit full family participation and individual responsibility; the smaller board size that characterises family firms may support this. Other explanations of smaller family firm boards include: family firms becoming intimidated by boards, setting up boards which may be merely cosmetic; and board member remuneration being an expense most family firms would be reluctant to bear.

Thus, we should expect:

H2: Family firm boards will be smaller than non-family firms' ones.

\section{Duality}

Whether the CEO also holds the post of Chairman of the board may also influence the independent judgement of the board. This may result in conflicts of interests (Brickley et al. 1997; Dalton \& Kesner 1987; Shivdasani \& Yermack 1999) as the CEO may have incentives to 'capture' the board and reduce its monitoring role in order to ensure that he can keep his job and increase his private benefits of control (Hermalin \& Weisbach 2001). Theoretical arguments may, nevertheless, be different for family firms. If the main role of the board is to assist managers, not to monitor them, duality may not be necessarily harmful. Within family firms, if the CEO and the Chairman are both family members, or even if they are the same person, the conflicts of interests may be less severe and duality may ease family firm governance. Thus, a family CEO could be considered a strength for a family firm. For instance, Bennedsen et al. (2006) consider that family CEOs could perform better than other managers because they are exposed to higher non-monetary rewards associated with firm success. Moreover, they may have hard-to-obtain, firm-specific knowledge, higher levels of trust from key stakeholders and could have a broader focus. However, family CEOs might not maximize shareholder wealth due to the existence of conflicts of interests between family and firm objectives, and they may be selected from a small pool of managerial talent (Bukart et al. 2003).

Due to the power exercised by families as large shareholders in family firms, we should expect 
duality to be present to a larger extent within family firms. Moreover, duality could be correlated with the generation in charge of the firm. At the founder stage, duality would be expected to be quite common with CEO and Chairman of the firm as founder; while as generations pass, and specially, after the third generation, the presence of duality would be less pronounced.

Thus, we should expect:

$H 3 a$ : Family firms will present more duality than non-family firms.

$H 3 b$. Duality in family firms will decrease as the family business moves through the generations.

\section{CEO or Chairman tenure}

Defined as the number of years a Chairman or CEO has occupied the post since his/her appointment, tenure may also be relevant from a corporate governance perspective. For family firms, longer CEO or Chairman tenure could suggest a long-term commitment to the firm (Ellul et al. 2006), frequently cited as a positive aspect of family firms. Longer tenures facilitate lengthy investment time horizons and provide investment incentives and stewardship (Le Breton-Miller \& Miller 2006:733). On the other hand, longer $\mathrm{CEO}$ and Chairman tenure may contribute to $\mathrm{CEO}$ or Chairman entrenchment.

Given the greater power and involvement of families in family firm governing bodies, we should expect that:

H4: Family firm CEO and Chairman tenures will be longer than non-family firm tenures.

\section{Board committees}

Comittees may also enhance board efficiency. Empirical studies show that the existence of internal committees (Klein 1998; Kose \& Lemma 1998) may influence the boards' monitoring role and that, for example, audit committee independence increases with board size and board independence (Klein, 2002). Most Codes of Best Practice actually recommend the exis- tence of a large set of independent directors on board committees, especially on audit, nominating, and remuneration committees. Families may be less eager to establish board committees owing to the smaller size of family firms and also to their lower will to establish monitoring devices. Moreover, if boards are overrepresented by family nominee and executive directors, in family firms, board committees will also be expected to reflect this fact, especially in relation to nominee directors.

We summarise these arguments in the following hypotheses:

H5a: Family firms will establish fewer voluntary committees (nominations and remuneration, strategy, or executives committees) than non-family firms.

H5b: Family firm board committees will be mainly controlled by family directors, and as a consequence they will have a lower degree of independence (fewer independent directors in favour of family nominees and executive directors) than those of non-family firms.

\subsection{Family firm ownership structures and corporate governance}

Family firms display different forms and tendencies in different institutional environments; Gnan et al. (2004) consider it impossible to define a universal type of family firm. We define two types of family firms which differ mainly in their ownership structures - that is, in the way families hold their shares - which we name Type I and Type II family firms.

\section{Type I family firms (FF1)}

Under this criterion, a firm is considered a family firm when it is owned directly or indirectly by an individual or a family who is the firm's main owner. That is, if a family or individual hold more shares than the rest of the other significant shareholders, with a minimum threshold of $10 \%$, the firm is considered as a family firm under the FF1 definition. This definition of a family firm based on 
ownership criteriaii has already been used in the literature, with variations in the level of the threshold chosen by different authors (Anderson \& Reeb 2003; Maury 2005; Villalonga \& Amit 2006).

\section{Type II family firms (FF2)}

Pyramids are mechanisms that facilitate the expropriation of minority shareholder wealth ( $\mathrm{La}$ Porta et al. 1998). As a result, the control rights of large shareholders may exceed their cash flow rights and large shareholders may have incentives to extract private benefits from control. Families, as large shareholders, may abuse their dominant position and extract private benefits at the expense of minority shareholders, especially in the presence of weak protection for minority shareholders (La Porta et al. 1998).

For the purpose of this paper, we define a second type of family firm. FF2 family firms are firms whose controlling shareholder (the largest shareholder) is not apparently an individual or a family - or is not a firm which is owned indirectly by a family through indirect ownership - but rather a firm whose controlling shareholder (with a threshold of $10 \%$ ) is a non-financial firm, and that when following the ownership structure backwards, the family is at the end of the chain of control.

From an agency point of view, as pyramids may trigger governance problems - increasing the possible expropriation of minority shareholders' wealth and managerial entrenchment (Morck \& Yeung 2004) - corporate governance structures may differ for Type I and Type II family firms. Therefore, we propose the following hypothesis:

H6: FF2 firms will have, to a larger extent, corporate governance structures that may enhance insider entrenchment and opportunistic behav- iour (larger board size, less board independence, fewer board committees, more duality, and longer Chairman tenure) than FF1 firms.

\section{DATA AND VARIABLES}

\subsection{Sample}

Our initial database comprises all companies quoted on the Electronic Market of the Madrid Stock Exchange at the end of 2004. Observations for financial companiesiii (SIC codes 60-64) were excluded from the initial database owing to their different regulatory and governance characteristics. Foreign companies listed on the Madrid Stock Exchange, for which we were not able to follow their ownership control chains were also excluded. We also excluded from the sample those companies that had not filled in the Annual Corporate Governance Report at the Spanish Supervisory Agency (Comisión Nacional del Mercado de Valores [CNMV]). After applying these filters, the number of non-financial companies included in the sample stood at 132 $(67.34 \%$ of the non-financial firms traded on the Madrid Stock Exchange).

Firm accounting data were supplied by the Madrid Stock Exchange. We manually collected data on significant shares and board composition from the data filled in by the companies at the Spanish Supervisory Agency and the companies' Annual Corporate Governance Reports for the year 2004.

FF1 firms amount to 31 cases out of the 132 sample firms. They belong mainly to the real estate industry (65 SIC code): $22.5 \%$ of FF1 firms. FF2 firms amount to 35 cases and belong mainly to holdings and other investment offices industries (67 SIC Code): 17.14\% of FF2 firms. When taking into account both types of family

ii Although we only measure ownership to define FF1 firms and not the presence of the family in the board of directors, these two concepts are related. Ownership or control rights implies chairs in the board of directors. Therefore, to define a firm as a FF1, taking into account other criteria, for example, family presence on board, does not add anything new, as families also controlled the board of directors.

iii Several studies report the differences between financial and non-financial firms (Prowse 1997; Stoney \& Winstanley 2001; Macey \& O’Hara 2003). 
firms simultaneously (FF), the number of family firms amounts to half of the sample firms: 66 cases. Again, family firms belong mainly to the real estate industry $(16.66 \%)$, to the holdings and other investment offices industry (67 SIC code, $12.12 \%)$ and to the food and kindred products industry (20 SIC code, 10.6\%). Non-family firms (NFF, 66 cases), come mainly from the holding and other investment offices industry (67 SIC code, $14.85 \%$ ) and to the electric, gas and sanitary services (49 SIC code, 12\%). These data reveal the importance of family firms among Spanish listed firms as already pointed out by previous studies (Galve \& Salas 1993; La Porta et al. 1999).

\subsection{Variables: description and methodology}

Table 1 describes the main variables employed in the study. Different variables refer to: firm ownership structure (Table 1, Panel A); corporate governance characteristics (Table 1, Panel B) - board of directors composition, other corporate governance variables, board committees, composition of board committees; and some family firm variables that relate to the family influence within the board of directors (Table 1, Panel C).

All corporate governance variables have been measured for family firms (FF), and for non-family firms (NFF). The FF definition jointly considers

TABLE 1: DesCriPtION OF VARIABLES

Variables Description

\section{PANEL A: OWNERSHIP STRUCTURE}

Owncon Continuous variable that measures the stock held by the four largest shareholders excluding directors' holdings

Dirowns Continuous variable that measures the percentage of stock in the hands of the board of directors

Freefloat Continuous variable that measures the stock ownership in the hands of minority investors (100\% - OWNCON)

\section{PANEL B: CORPORATE GOVERNANCE VARIABLES}

\section{Board of Directors' Composition}

Bexdir Percentage of executive directors (insiders) over total number of directors

Bmaindir Percentage of directors representing major shareholders (outsiders) over total number of directors

Bindpdir Percentage of directors representing independent shareholders (outsiders) over total number of directors

Bodir Percentage of grey outside directors over total number of directors

Boutdir Percentage of outside directors (BMAIN+BINDP+BODIR)

Binsmaindir Sum of insiders and nominee directors over total number of directors

\section{Other Corporate Governance Variables}

Bsize Number of directors

Dual Dummy variable that adopts value 1 if the CEO and Chairperson is the same person and 0 otherwise

Chairtenure Continuous variable that measures the number of years the Chairperson has been occupying the post (2006 minus first appointment year)

Famceo $\quad \%$ of family firms where the CEO is a family member

Famchairman \% of family firms where the Board Chairperson is a family member

\section{Board Committees Existence}

Excom Dummy variable that measures whether the executive committee exists

Auditcom Dummy variable that measures whether the audit committee exists

Nomcom Dummy variable that measures whether the nominating and remuneration committee exists

Strategycom Dummy variable that measures whether the strategy committee exists

(Continued) 
TABLE 1: DESCRIPTION OF VARIABLES (Continued)

\section{Variables Description \\ Board Committee Composition}

Mainexdir Number of main shareholder directors on the executive committee over total directors on the executive committee

Indpexdir Number of independent directors on the executive committee over total directors on the executive committee

Exexdir Number of executive directors on the executive committee over total directors on the executive committee

Otexdir Number of others directors on the executive committee over total directors on the executive committee

Mainauditdir Number of main shareholder directors on the auditing committee over total directors on the auditing committee

Indpauditdir Number of independent directors on the auditing committee over total directors on the auditing committee

Exauditdir Number of executive directors on the auditing committee over total directors on the auditing committee

Otauditdir Number of other directors on the auditing committee over total directors on the auditing committee

Mainnomdir Number of main shareholder directors on the nominating committee over total directors on the nominating committee

Indpnomdir Number of independent directors on the nominating committee over total directors on the nominating committee

Exnomdir Number of executive directors on the nominating committee over total directors on the nominating committee

Otnomdir Number of other directors on the nominating committee over total directors on the nominating committee

Mainstrdir Number of main shareholder directors on the strategy committee over total directors on the strategy committee

Indpstrdir Number of independent directors on the strategy committee over total directors on the strategy committee

Exstrdir Number of executive directors on the strategy committee over total directors on the strategy committee

Otstrdir Number of other directors on the strategy committee over total directors on the strategy committee

\section{PANEL C: FAMILY FIRM VARIABLES}

FF1 Dummy variable that adopts value 1 if a firm is owned directly or indirectly by an individual or a family who has more shares than the rest of the significant shareholders together (over the $10 \%$ threshold), and zero otherwise

FF2 Dummy variable that adopts value 1 if there is a pyramidal structure and the ultimate owner (when following chains of control) is a family or an individual who has more shares than the rest of the significant shareholders together, and zero otherwise

FF Dummy variable that adopts one if the firm is considered a family firm either by criteria one (FF1) or criteria two (FF2) and zero otherwise

NFF Dummy variable that adopts one when the firm is not a family firm and zero otherwise

Generation Dummy variable that adopts for family firms value one if the family firm is on the second or subsequent generation and zero otherwise (first generation)

Nff1 Inside the FF1 firms, NFF1 is a dummy variable that adopts value 1 if a firm is not defined as an FF1 firm and zero otherwise

Nff2 Inside the FF2 firms, NFF2 is a dummy variable that adopts value 1 if a firm is not defined as an FF2 firm and zero otherwise 
Do families shape corporate governance structures?

TABLE 1: DESCRIPTION OF VARIABLES (Continued)

\begin{tabular}{|c|c|}
\hline Variables & Description \\
\hline Famex & Percentage of family executive directors (insiders) over total number of executive directors \\
\hline Fammain & $\begin{array}{l}\text { Percentage of family directors representing major shareholders (outsiders) over total } \\
\text { number of main directors }\end{array}$ \\
\hline Famindp & $\begin{array}{l}\text { Percentage of family directors representing independent shareholders (outsiders) over total } \\
\text { number of independent directors }\end{array}$ \\
\hline Famot & Percentage of family grey outside directors over total number of grey directors \\
\hline Famacom & Number of family directors on the audit committee over total directors on the audit committee \\
\hline Famnomcom & $\begin{array}{l}\text { Number of family directors on the nominating committee over total directors on the } \\
\text { nominating committee }\end{array}$ \\
\hline Famexcom & $\begin{array}{l}\text { Number of family directors on the executive committee over total directors on the } \\
\text { executive committee }\end{array}$ \\
\hline Famstratgcom & $\begin{array}{l}\text { Number of family directors on the strategy committee over total directors on the strategy } \\
\text { committee }\end{array}$ \\
\hline Size (AT) & Firmtotal assets in thousand euros \\
\hline
\end{tabular}

the two types of firms defined under the criteria (FF1 and FF2). A family firm is defined as a firm whose main largest shareholder (either direct, indirect or through a pyramidal structure) is a family. NFF firms include all the firms that do not fit within this definition.

The significance of possible differences in the corporate governance structures of family versus non-family firms and FF1 and FF2 family firms (in mean valuesiv) was tested using the non-parametric tests (Mann-Whitney U tests). A Chisquared test was run to test statistical differences for dichotomous variables.

\section{RESULTS}

Table 2 provides descriptive statistics for the whole sample. The mean size ${ }^{v}$ of the firms in the sample is 1,881,035 euros. On average, for all sample firms, the four largest shareholders (OWNCON) hold $50.71 \%$ of firm shares. This figure highlights the high ownership concentration of Spanish quoted companies as already reported by previous studies (Sacristán \& Gómez 2007; La Porta et al.
1999). Director ownership (DIROWNS) stands at $23.2 \%$ (mean value) with a maximum of $95.75 \%$. Boards of directors are mainly comprised of nominee directors (42\%), followed by independent directors (32\%), and executive directors (22\%). In sum, outsider directors represent $77 \%$ of Board. The mean board size is 10.27 directors. Duality is present in about half of the sample, and Chairman tenure is average 13 years. Regarding Board committees, almost all the firms have a mandatory audit committee (98\%), more than $60 \%$ have a nominating and remuneration committee $(66 \%$ of the firms) and less than $50 \%$ have an executive committee ( $42 \%$ of the firms), but only $11 \%$ of sample firms have a strategy committee. The composition of Board committees also reflects the importance of nominee directors within Spanish firms. Nominee directors are highly represented within the executive committee (23\% of members) and nominating and remuneration committee $(35 \%$ of members), while independent directors are the main group within the auditing committee ( $44 \%$ of members).

iv Differences in corporate governance structures for the sub-samples of firms (in median values) were also tested. The results are similar as when using median differences and are therefore not reported.

$\mathrm{v}$ Although not shown, as expected, a lot of the variables that have been analysed are strongly correlated. Size is positively correlated with the existence of the Nominating and Remuneration committee and with the existence of the Executive committee. Size is also positively related to board size and free float but negatively related to the proportion of insider directors. 
TABLE 2: DESCRIPTIVE STATISTICS

Mean/\%

(dichotomous

Variable variables)

Median

SD

Min

Max

Ownership Structure

\begin{tabular}{llllrrr}
\hline Owncon & 131 & $50.71 \%$ & $52.26 \%$ & 23.49 & $0.07 \%$ & $99.33 \%$ \\
Dirowns & 132 & $23.22 \%$ & $11.27 \%$ & 2.5 & 0 & $95.75 \%$ \\
FreeFloat & 131 & $49.29 \%$ & $47.74 \%$ & 23.49 & $0.67 \%$ & $99.9 \%$ \\
\hline
\end{tabular}

Board of Directors Composition

\begin{tabular}{lrrrrrr}
\hline Bexdir & 132 & $22 \%$ & $18 \%$ & $16 \%$ & 0 & $67 \%$ \\
Bmaindir & 132 & $42 \%$ & $41 \%$ & $26 \%$ & 0 & $100 \%$ \\
Bindpdir & 132 & $32 \%$ & $33 \%$ & $21 \%$ & 0 & $89 \%$ \\
Bodir & 132 & $3.5 \%$ & 0 & $9.7 \%$ & 0 & $60 \%$ \\
Boutdir & 132 & $77 \%$ & $81 \%$ & $16 \%$ & $33 \%$ & $100 \%$ \\
Binsmaindir & 132 & $64 \%$ & $66 \%$ & $22 \%$ & 0 & $100 \%$ \\
\hline
\end{tabular}

\section{Other Corporate Governance Variables}

\begin{tabular}{|c|c|c|c|c|c|c|}
\hline Bsize & 131 & 10.27 & 10 & 4.181 & 3 & 21 \\
\hline Dual & 132 & $55 \%$ & 1 & 0,50 & 0 & 1 \\
\hline Tenure & 132 & 13.05 & 9 & 11.69 & 2 & 64 \\
\hline
\end{tabular}

Board Committee Existence

\begin{tabular}{llllrrr}
\hline Excom & 131 & $42 \%$ & 0 & $5 \%$ & 0 & 1 \\
Auditcom & 131 & $98 \%$ & 1 & $12.3 \%$ & 0 & 1 \\
Nomcom & 131 & $66 \%$ & 1 & $47.4 \%$ & 0 & 1 \\
Strategycom & 131 & $11 \%$ & 0 & $32 \%$ & 0 & 1 \\
\hline
\end{tabular}

\section{Board Committees Composition}

\begin{tabular}{lrrrrrr}
\hline Mainexdir & 92 & $23 \%$ & 0 & $29 \%$ & 0 & 1 \\
Indpexdir & 92 & $13 \%$ & 0 & $20 \%$ & 0 & $75 \%$ \\
Exexdir & 92 & $20 \%$ & $16 \%$ & $24 \%$ & 0 & 1 \\
Otexdir & 92 & $2.6 \%$ & 0 & $13.2 \%$ & 0 & 1 \\
Mainauditdir & 127 & $41 \%$ & $33 \%$ & $30 \%$ & 0 & 1 \\
Indpauditdir & 127 & $44 \%$ & $40 \%$ & $29 \%$ & 0 & 1 \\
Exauditdir & 127 & $9.5 \%$ & 0 & $14.4 \%$ & 0 & $40 \%$ \\
Otauditdir & 127 & $4.7 \%$ & 0 & $14 \%$ & 0 & $67 \%$ \\
Mainnomdir & 103 & $35 \%$ & $33 \%$ & $30 \%$ & 0 & 1 \\
Indpnomdir & 106 & $34 \%$ & $33 \%$ & $31 \%$ & 0 & 1 \\
Exnomdir & 106 & $9 \%$ & 0 & $16 \%$ & 0 & $67 \%$ \\
Otnomdir & 106 & $4.1 \%$ & 0 & $13 \%$ & 0 & $67 \%$ \\
Mainstrdir & 119 & $3.8 \%$ & 0 & $14 \%$ & 0 & $75 \%$ \\
Indpstrdir & 119 & $3.9 \%$ & 0 & $14 \%$ & 0 & $75 \%$ \\
Exstrdir & 119 & $1.7 \%$ & 0 & $8.2 \%$ & 0 & $67 \%$ \\
Otstrdir & 119 & $1 \%$ & 0 & $3.8 \%$ & 0 & 0 \\
\hline Others & & & & & 0
\end{tabular}

Others

\begin{tabular}{lllllll}
\hline AT & 132 & $1,881,035$ & 259,064 & $5,655,265$ & 2,161 & $51,497,250$ \\
\hline
\end{tabular}




\subsection{Family firm corporate governance structures: Differences between family firms and non-family firms}

Following hypotheses 1 to 5 , we analyse possible differences between family and non-family firm corporate governance structures (Table 3).

The results suggest no significant differences in firm ownership concentration or free-float, although family firm directors do own a larger fraction of firm shares (as a mean). Family firm director ownership amounts to an average $33.53 \%$, while for non-family firms it is $12.90 \%$ - significant at $p<0.01$. Differences found in director ownership between family and non-family firms are in line with US results (Anderson \& Reeb 2003; Villalonga \& Amit 2006), revealing that family firm directors, especially nominee and inside directors, hold significant stakes in firm shares.

The proportion of internal or executive directors (BEXDIR) is also different for FF and NFF firms. On average, family firm boards have more executive directors $(27 \%)$ than non-family firms $(17 \%)$, significant at $p<0.01$. This result supports H1 which predicts that family firms should present a lower proportion of independent directors.

What is surprising, and contradicts $\mathrm{H} 1$, is that family firms have fewer nominee directors (on average, $38 \%$ ) than non-family firms (47\%), significant at $p<0.05$. This difference may be partially due to the fact that family influence may not only be reflected in the figures of nominee directors. Family members may be part of firm management teams, and consequently be represented within the Board as executive directors. The results show that the joint proportion of executive and nominee directors is similar for family and non-family firms. Furthermore, the proportion of independent directors does not differ for family (30\%) and non-family firms $(33 \%)$. Summing up, family firms have more executive directors (that is, insiders) and conse- quently fewer outside directors (BOUTDIR) (on average, $72 \%$ for $\mathrm{FF}$ versus $83 \%$ for NFF), significant at $p<0.01$. These results are similar to those reported for $S \& P 500$ firms in the US by Ali et al. (2007). For the UK, Hillier and McColgan (2004) also report statistical differences for outside directors between family and non-family firms.

Our results suggest no under-representation of independent directors among family firm boards or over-representation of nominee directors, but an under-representation of outside directors. Family firm boards seem to be more dominated by insiders, who are most likely family members but do not present a lower proportion of independent directors in favour of nominee directors as was proposed in Hypothesis 1.

Relating to board size, the mean value of board size (BSIZE) stands at 10 directors, which is lower than the maximum of 15 directors established by the Spanish Unified Code of Best Practice (2006). This figure is similar to the one reported for the US by Barnhart et al. (1994) and Yermack (1996) (about 12 directors). For the UK, Franks \& Mayer (1997) report a mean board size of 8 directorsvi. While family firm boards comprise an average 9.27 directors, non-family firms comprise an average 11.29 directors; significant at $p<0.05$. A similar result was obtained by Hillier and McColgan (2004) in the UK. In contrast, Batholomeusz and Tanewski (2006) did not find differences in board size between FF and NFF. Our results suggest that family firm boards are smaller than non-family firms, as proposed by Hypothesis 2, probably in part because of the smaller size of family firms, but this may not be the only reason. Family control of the board may not be as easy as board size increases, and families may be reluctant to increase the number of directors so as to retain control.

CEO duality (DUAL) accounts for 55\% of cases for the whole sample. Although as a mean,

vi Nevertheless, one has to consider that, given the smaller size of Spanish listed firms, board sizes are larger than for the comparable company in the US. 
duality in family firms is slightly higher (59\%) not statistically significant. These results do not than in non-family firms $(52 \%)$, the difference is support $\mathrm{H} 3 \mathrm{a}$.

TABle 3: Differences between family (FF) AND NON-FAmily fiRms (NFF) (MEAN VAlues)

\begin{tabular}{|c|c|c|c|c|}
\hline Variable & $\begin{array}{l}\text { FF mean }(n=66) / \\
\% \text { (dichotomous } \\
\text { variables) }\end{array}$ & $\begin{array}{l}\text { NFF mean }(n=66) / \\
\% \text { (dichotomous } \\
\text { variables) }\end{array}$ & Mean difference & $\begin{array}{c}\text { DIFFFNFF } \\
\text { Mann Whitney-U (Z) } \\
\text { /Chi-squared } \\
\text { (dichotomous variables) }\end{array}$ \\
\hline Owncon & $51.38 \%$ & $50.03 \%$ & $1.35 \%$ & -0.377 \\
\hline Dirowns & $33.53 \%$ & $12.91 \%$ & $20.62 \%$ & $-4.93^{\star \star \star}$ \\
\hline FreeFloat & $48.62 \%$ & $49.97 \%$ & $-1.35 \%$ & -0.38 \\
\hline Bexdir & $27 \%$ & $17 \%$ & $10 \%$ & $-4.028^{\star \star \star}$ \\
\hline Bmaindir & $38 \%$ & $47 \%$ & $-9 \%$ & $-1.985^{\star \star}$ \\
\hline Bindpdir & $30 \%$ & $33 \%$ & $-3 \%$ & -0.25 \\
\hline Bodir & $4 \%$ & $3 \%$ & $1 \%$ & -0.72 \\
\hline Boutdir & $72 \%$ & $83 \%$ & $-11 \%$ & $-4.13^{\star \star \star}$ \\
\hline Binsmaindir & $65 \%$ & $63 \%$ & $2 \%$ & -0.05 \\
\hline Bsize & 9.27 & 11.29 & $-2 \%$ & $-2.93^{\star \star}$ \\
\hline Dual & $59 \%$ & $52 \%$ & $5 \%$ & 0.76 \\
\hline Tenure & 16.24 & 9.86 & 6.38 & $-3.29 \star \star \star$ \\
\hline Excom & $34 \%$ & $50 \%$ & $-16 \%$ & $3.51^{\star}$ \\
\hline Auditcom & $100 \%$ & $97 \%$ & $3 \%$ & 2 \\
\hline Nomcom & $57 \%$ & $76 \%$ & $-19 \%$ & $5.2^{\star \star}$ \\
\hline Strategycom & $12 \%$ & $11 \%$ & $1 \%$ & 0.094 \\
\hline Mainexdir & $15 \%$ & $30 \%$ & $-15 \%$ & $-2.45^{\star \star}$ \\
\hline Indpexdir & $9 \%$ & $16 \%$ & $-7 \%$ & $-1.80^{\star}$ \\
\hline Exexdir & $25 \%$ & $17 \%$ & $8 \%$ & -0.54 \\
\hline Otexdir & $1 \%$ & $4 \%$ & $-3 \%$ & -0.35 \\
\hline Mainauditdir & $40 \%$ & $43 \%$ & $-3 \%$ & -0.59 \\
\hline Indpauditdir & $42 \%$ & $46 \%$ & $-4 \%$ & -0.54 \\
\hline Exauditdir & $13 \%$ & $6 \%$ & $7 \%$ & $-3.07^{\star \star}$ \\
\hline Otauditdir & $5 \%$ & $5 \%$ & 0 & -0.06 \\
\hline Mainnomdir & $32 \%$ & $38 \%$ & $-6 \%$ & -0.95 \\
\hline Indpnomdir & $34 \%$ & $35 \%$ & $-1 \%$ & -0.32 \\
\hline Exnomdir & $8 \%$ & $10 \%$ & $-2 \%$ & -0.36 \\
\hline Otnomdir & $4 \%$ & $4 \%$ & $0 \%$ & 0 \\
\hline Mainstrdir & $5 \%$ & $3 \%$ & $2 \%$ & -0.74 \\
\hline IndpStrdir & $3 \%$ & $5 \%$ & $-2 \%$ & -0.02 \\
\hline Exstrdir & $2 \%$ & $1 \%$ & $1 \%$ & -0.45 \\
\hline Otstrdir & $1 \%$ & $1 \%$ & 0 & -0.61 \\
\hline$\overline{\text { AT }}$ & 603.878 & 3.158 .193 & -2.554 .315 & $-3.31^{\star \star \star}$ \\
\hline
\end{tabular}

FF is a dummy variable that adopts one if the firm is considered a family firm either by criteria one (FF1) or criteria two (FF2) and zero otherwise.; NFF is a dummy variable that adopts one when the firm is not a family firm and zero otherwise, DIFFFNFF is a dummy variable that adopts value 1 if the firm is a FF firm and zero if the firm is a non-family firm. For dichotomous variables a pearson chi-squared test was run.

${ }^{\star \star *} p<0.001 ;{ }^{* \star} p<0.05 ;{ }^{*} p<0.10$ 
Table 4 relates duality with the family generations: 16 family firms are first generation firms, while 50 firms are run by second or subsequent generations. Duality is found in 39 of the family firms, but the chi-squared test reveals no association between duality and family generations, thus the results do not confirm Hypothesis $3 b$.

Regarding Chairman tenure in family firms, they amount on average to 16.25 years, a figure substantially higher than that found for non-family firms (9.8 years); significant at $p<0.01$ vii. This result supports Hypothesis 4.

Regarding board committee existence ( $\mathrm{H} 5 \mathrm{a})$, we find no statistical differences between family and non-family firms for auditing committees (a mandatory committee in Spain). Looking at the non-compulsory committees, family firms tend to establish to a lesser extent nominating and remuneration committees (significant at $p<$ 0.05 ) as well as executive committees (significant at $p<0.10)$ than non FF. These results, although we must say that they may be partly related to firm size, seem to support $\mathrm{H} 5 \mathrm{a}$, and point to the lesser use that family firms may make of internal mechanisms of corporate governance.

Regarding the composition of the board committees $(\mathrm{H} 5 \mathrm{~b})$, the results show differences in the composition of the executive and auditing committees between family and non-family firms, but no differences are found for the nominating and remuneration committee or for the strategy committee. For the executive committee, differences between family and non-family firms are found regarding the proportion of nominee directors.
Non-family firms have more directors representing large shareholders $(30 \%)$ than family firms (15\%), (significant at $p<0.05$ ), but family firms have fewer independent directors (9\%) on the executive committee than non-family firms $(16 \%)$ (significant at $p<0.10$ level).

Auditing committees are comprised almost equally of directors representing large shareholders and independent directors. Nevertheless, it is worth noting that inside directors, contrary to what is recommended by most Codes of Best Practice, are still represented on this committee. Moreover, family firm auditing committees have more executive directors $(13 \%)$ than non-family firms (6\%); significant at $p<0.05$.

Within the nominating and remuneration committee, nominee directors (32\%) and independent directors (34\%) account for almost the same proportion, followed by executive directors $(8 \%)$ and grey directors (4\%). No statistical differences are found in the composition of the nominating and remuneration committees between family and non-family firms.

Finally, regarding the strategy committee, a residual committee that is only present in 15 firms, the composition does not differ between family and non-family firms.

Summing up, family firm executive committees are comprised of less nominee directors than those of non-family firms (nearly double the proportion), and present a lower proportion of independent directors. Also, family firm auditing committee composition is biased towards insiders (executive directors). These results support $\mathrm{H} 5 \mathrm{~b}$

\section{TABLE 4: RELATIONSHIP BETWEen DUALITY AND GENERATION FOR FAMILY FIRMS}

\begin{tabular}{|c|c|c|c|c|}
\hline Duality & First generation & Two or more generations & $n$ & Chi-squared test \\
\hline No & 8 & 19 & 27 & \\
\hline Yes & 8 & 31 & 39 & \\
\hline$n$ & 16 & 50 & 66 & 0.722 \\
\hline
\end{tabular}

vii We have deleted the firm which has the maximum value (64 years) and repeated all the empirical analysis and the results remain similar. Mean tenure of family firms is then 15.51 years and for NFF firms about 9.86 . The differences are still significant at 0.01 levels. 
only where it refers to the auditing committee. Similarly to what was observed for the whole board, family firm auditing committees seem to be over-represented by insiders.

\subsection{Family firm ownership structures and corporate governance}

In order to test H6, we analyse whether there are differences in corporate governance structures between the two types of family firms (FF1 and FF2) (see Table 5).
The sample contains 31 family firms under the FF1 definition, and 35 family firms under the FF2 definition. Although FF2 firm size, as a mean, is almost double FF1 firm size (significant at $p<0.10$ ), we do not find significant differences in their corporate governance structures. Family firms, despite their size, seem to establish similar corporate governance structures. Statistical differences between the two types of family firms - in terms of their corporate governance structures - are only found in: firm board size,

TABle 5: Differences between FF1 and FF2 corporate governance variables (MEAN VALUes)

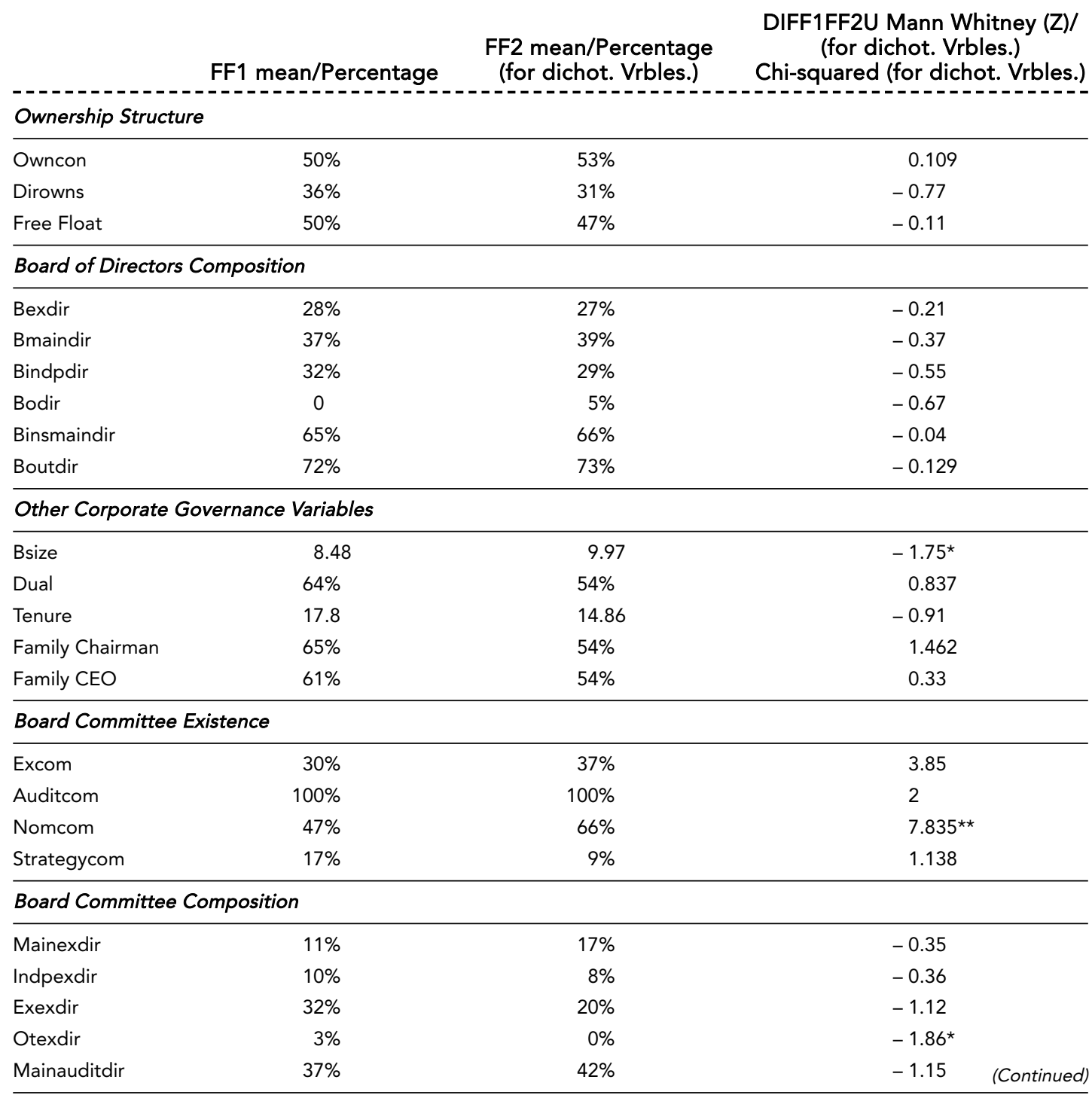


Do families shape corporate governance structures?

TAble 5: Differences betWeen FF1 and FF2 corporate governance variables (MEAN values) (Continued)

\begin{tabular}{lccc} 
& FF1 mean/Percentage & $\begin{array}{c}\text { FF2 mean/Percentage } \\
\text { (for dichot. Vrbles.) }\end{array}$ & $\begin{array}{c}\text { DIFF1FF2U Mann Whitney (Z)/ } \\
\text { (for dichot. Vrbles.) }\end{array}$ \\
\hline Indpauditdir & $43 \%$ & $41 \%$ & -0.05 \\
Exauditdir & $16 \%$ & $10 \%$ & -1.38 \\
Otauditdir & $3 \%$ & $6 \%$ & -0.62 \\
Mainnomdir & $27 \%$ & $34 \%$ & -0.78 \\
Indpnomdir & $31 \%$ & $36 \%$ & -0.26 \\
Exnomdir & $15 \%$ & $5 \%$ & $-2.20^{\star \star}$ \\
Otnomdir & $5 \%$ & $4 \%$ & -1.01 \\
Mainstrtdir & $6.6 \%$ & $3 \%$ & -1.09 \\
Indpstrtdir & $4 \%$ & $2 \%$ & -0.67 \\
Exstrtdir & $3.5 \%$ & $1 \%$ & -1.23 \\
Otstrtdir & $1.4 \%$ & $0 \%$ & 1.58
\end{tabular}

Family Firm Variables

\begin{tabular}{lcrl}
\hline Famex & $44 \%$ & $42 \%$ & -0.23 \\
Fammain & $31 \%$ & $34 \%$ & -0.66 \\
Famindp & $3.8 \%$ & $1 \%$ & -1.18 \\
Famot & $0 \%$ & $3 \%$ & $-1.65^{\star}$ \\
Famacom & $18 \%$ & $23 \%$ & -0.83 \\
Famexcom & $17 \%$ & $17 \%$ & -0.38 \\
Famnomcom & $25 \%$ & $18 \%$ & -1.11 \\
Famstratgcom & $2 \%$ & $2 \%$ & -0.178 \\
Generation & $71 \%$ & $80 \%$ & 0.730 \\
\hline
\end{tabular}

Others

\begin{tabular}{lccc}
\hline SIZE & 316.869 & 858.086 & $-1.88^{\star}$ \\
\hline Number of firms & 31 & 35 &
\end{tabular}

FF1 is a dummy variable that adopts value 1 if a firm is owned directly or indirectly by an individual or a family who has more shares than the rest of the significant shareholders together (over the $10 \%$ threshold), and zero otherwise. FF2 is a dummy variable that adopts value 1 if there is a pyramidal structure and the ultimate owner (when following chains of control) is a family or an individual who has more shares than the rest of all the significant shareholders together, and zero otherwise. DIFFF1FF2 is a qualitative variable that adopts value 1 if the family firm is a FF1 firm and two if the family firm is a family firm under the FF2. For dichotomous variables a pearson chi-squared test was run.

${ }^{\star \star *} p<0.01 ;{ }^{* \star} p<0.05 ;{ }^{\star} p<0.10$.

board committee existence, board committee composition and the type of family directors.

Regarding board characteristics, FF2 firms have slightly larger boards (significant at $p<0.10$ ) than FF1. This result supports partially H6, but we find that other board characteristics - such as duality, CEO tenure, family chairperson, family CEO or family members among firm top executives - are similar for FF1 and FF2 family firms.

Regarding board committees, FF1 firms seem to use less internal control devices than FF2 firms. FF1 firms establish less nominating and remuneration committees than FF2 (47\% of the cases versus $66 \%$ of the cases; significant at $p<$ 0.05), but other differences do not turn out to be statistically significant.

Regarding board committees' composition, again we do not find many differences between FF2 and FF1, although FF1 executive committees have a larger proportion of other type of directors $(3 \%)$ (significant at $p<0.10)$ than FF2 $(0 \%)$. 
For the nominating and remuneration committee, we again find no statistical differences between both types of firms except in the proportion of executive directors. FF1 firms have more executives on this committee than FF2 firms (15\% versus 5\%; significant at $p<0.05)$, but no differences are found in the composition of auditing and strategy committee. These results contradict H6.

There are also no other differences between FF1 and FF2 regarding the number of firms that have a family Chairman, a family CEO, in the proportion of family directors, or in the proportion of different types of family directors within firm committees.

Summing up, these results do not confirm H6 as we do not find significant differences between FF1 and FF2 corporate governance structures. We only find differences in board size. As a consequence, we cannot affirm that differences in the way the family shareholders hold their shares determine family firm corporate governance structures.

Although not shown, when we analyze possible differences between FF1 and NFF1 and between FF2 and NFF2, the results confirm that differences are really driven by the idiosyncrasy of being a family firm, more than by the use of control devices. In FF1 firm directors hold larger fractions of firm shares and the proportion of executive directors is larger. The number of outside directors is larger for NFF1 firms than for FF1 firms. FF1 firm board size is smaller than NFF1 firms and Chairman tenures are longer for FF1 firms. FF1 firms use the nominating and remuneration committees less than NFF1 firms, and have more insiders in the auditing committee and nominating and remuneration committee. More types of directors within the strategy committee are present in FF1 firms than for NFF1 firms. When comparing FF2 with NFF2, the results are similar.

These results reinforce the idea that differences in firm corporate governance structures are mainly in the family origin of the firms, and not in the control devices used by families.

\section{DISCUSSION AND CONCLUSION}

This paper describes the main differences in firm corporate governance structures between family firms and non-family firms, and analyses whether different family ownership configurations affect corporate governance structures. It aims only to describe family firm board characteristics in the Spanish context and not to prescribe family board best practices.

The results suggest that board characteristics are not linked to different family ownership configurations. Pyramidal structures do not seem to alter family firm board composition but family firm corporate governance structures do exhibit characteristics of Continental models of corporate governance - which involve companies with a concentrated shareholder base and family members active in management and the board. As a result, Spanish family firm boards tend to be dominated by insiders (who are mostly family members). Moreover, for family firms, Chairman tenure is longer than for non-family firms. Whether using pyramidal structures or not, families, when present, seem to hold the majority of the shares and control of the firms in which they invest. Directors hold more shares in family firms than in non-family firms. Also, family firm use of committees is lower compared to non-family firms. The higher percentage of executive directors within family firms is also reflected in the composition of the auditing and the executive committees.

Summing up, these results suggest an insider control of corporate governance structures for family firms, owing to a higher presence of family executive directors on family firm boards. The fact that family firm boards show a lower percentage of nominee directors points to the higher involvement of families in firm management.

From an agency point of view, these characteristics of family firms could lead to the entrenchment of families and opportunistic behaviours. Furthermore, these characteristics contradict the recommendations of most Codes of Best Practice, since they may contribute to the possibility of extraction of private benefits from control by 
Do families shape corporate governance structures?

families. Nevertheless, one has to remember that these Codes have frequently been written from an agency theory perspective and may not have taken into account the specificities of family firms. Distinctive family corporate governance practices may not necessarily be negative as the effect of family control could be better than professional control.

This research suggests the importance of corporate governance for family firms and the need to continue studying this topic. Academics need to adapt corporate governance prescriptions to family firm characteristics. We have studied the implications of different family ownership configurations in a descriptive way, but further implications, particularly the impact of such differences on firm value, should also be analyzed.

The managerial implications of the paper suggest that family firms should be proud of being different. To have small, active but internal boards could be fine. Only strategy dysfunctions could motivate organizational changes and board composition changes. Family firm associations may promote corporate governance codes to maintain these differential characteristics and advance family firm corporate governance practices.

Further implications of the paper are related to policy makers. Laws and Codes should respect family firm differences. Laws should not enforce a uniform behaviour. Codes of Best Practices, soft-laws, are mainly based on the corporate governance practices of non-family firms, and may not be adequate for family firms.

Future studies could relate family firm corporate governance differences to firm value and adopt a longitudinal perspective. Future studies could also analyse the reason for employing pyramidal structures in the presence of sufficient control power by families.

\section{ACKNOWLEDGEMENTS}

The authors would like to acknowledge the financial support of Project ECO2008-01439 funded by the Spanish Ministry of Innovation and Technology.

\section{References}

Ali A, Chen TY and Rodhakrishnan S (2007) Corporate disclosures by family firms, Journal of Accounting and Economics 44(1-2): 238-286.

Anderson RC and Reeb DM (2003) Foundingfamily ownership and firm performance: evidence from the S\&P 500, Journal of Finance LVIII (3): 1301-1328.

Anderson RC and Reeb DM (2004) Board composition: balancing family influence in S\&P 500 firms, Administrative Science Quarterly 49: 209-237.

Barney J and Hansen M (1994) Trust worthiness as a source of competitive advantage, Strategic Management Journal 15: 175-190.

Barnhart SW, Marr MW and Rosenstein S (1994) Firm performance and board composition: some new evidence, Managerial and Decision Economics 15: 329-340.

Barth E, Gulbrandsen T and Schonea P (2005) Family ownership and productivity: the role of owner management, Journal of Corporate Finance 11: 107-127.

Bartholomeusz S and Tanewski GA (2006) The relationship between family firms and corporate governance, Journal of Small Business Management 44(2): 245-267.

Bennedsen M, Meisner K, Pérez-González F and Wolfenzon D (2006) Inside the Family Firm: The role of families in succession decisions and performance. Finance Working Paper No.132 (http://ssrn.com/abstract_id=925650).

Brickley J, Coles JL and Jarrell G (1997) Leadership structure: Separating the CEO and Chairman of the Board, Journal of Corporate Finance 3: 189-220.

Bukart M, Panunzi F and Shleifer A (2003) Family Firms, Journal of Finance LVIII (5): 2167-2201.

Carney M (2005) Corporate governance and competitive advantage in family controlled firms, Entrepreneurship Theory and Practice, 29(3): 249-265.

Chrisman JJ, Steier LP and Chua JH (2006) Personalism, particularism and the competitive behaviours and advantages of family firms: an introduction, Entrepreneurship Theory and Practice 30(6): 719-729.

Claessens S, Djankov S, Fan J and Lang LH (2002) Disentangling the incentive and entrenchment effects of large shareholders, Journal of Finance LVII (6): 2741-2771.

Corbetta G and Salvato C (2004) The board of directors in family firms: one size fits all? Family Business Review 17: 119-134.

Dalton DR and Kesner IF (1987) Composition and CEO duality in boards of directors: an 
international perspective, Journal of International Business Studies 18(3): 33-42.

Davis JA and Taguiri R (1989) The influence of life stage on father-son work relationships in family companies, Family Business Review 2: 47-74.

Davis JH, Schoorman FD and Donaldson L (1997) The distinctiveness of agency theory and stewardship theory, Academy Management Review 22(3): 611-613.

Donckels R and Frohlick E (1991) Are family business really different? European experiences from STRATOS, Family Business Review 4(2): 149-160.

Eisenberg T, Sundge S and Wells M (1998) Larger board size and decreasing firm value in small firms, Journal of Financial Economics 48: 35-54.

Ellul A, Guntay L and Lei V (2006) 'External governance and debt agency costs of family firms'. Paper presented at the conference on Corporate Governance in Family/unlisted firms, Bern, Switzerland.

Faccio M and Lang L (2002) The ultimate ownership of western European corporations, Journal of Financial Economics 65: 365-395.

Fama EF and Jensen MC (1983) Separation of ownership and control, Journal of Law and Economics 26: 301-326.

Fernández AI, Gómez-Ansón S and Fernández Méndez C (1998) El papel supervisor del consejo de administración sobre la actuación gerencial. Evidencia para el caso español, Investigaciones Económicas 22(3): 501-516.

Franks J and Mayer C (1997) Corporate ownership and control in the UK, Germany and France, Journal of Applied Corporate Finance 9: 30-45.

Galve C and Salas Fumás V (1993) Propiedad y resultados de la gran empresa española, Investigaciones Económicas XVII (2): 207-238.

Gnan L, Schultze W, Montemerlo D and Corbetta G (2004) Governance structures in Italian Family SMEs, in Tomaselli LM (eds) Family firms in the wind of change, FBN Conference Proceedings, Copenhagen.

Habbershon TG and Williams ML (1999) A resource-based framework for assessing the strategic advantages of family firms, Family Business Review 12(1): 1-25.

Hermalin B and Weisbach M (1988) The determinants of board composition, Rand Journal of Economics 19(4): 589-606.

Hermalin BE and Weisbach MS (2001) Board of directors as an endogenously determined institution: a survey of the economics literature. NBER Working Paper 816.
Hillier DJ and McColgan PML (2004) Firm Performance, Entrenchment and Managerial Succession in Family Firms. Accessed at http://ssrn.com/abstract=650161

Hillman AJ, Cannella AA and Paerzold RL (2000) The resource dependence role of corporate directors: strategic adaptation of board composition in response to environmental change, Journal of Management Studies 37(2): 235-255.

Jaskiewicz P and Klein S (2007) The impact of goal alignment on board composition and board size in Family Business, Journal of Business Research 60(10): 1080-1089.

Jayaraman NA, Khorana E and Covin J (2000) CEO founder status and firm financial performance, Strategic Management Journal 21: 1215-1224.

Jensen M (1993) The modern industrial revolution, exit, and the failure of internal control systems, Journal of Finance 48(3): 831-880.

Klein A (1998) Firm performance and board committee structure, Journal of Law and Economics 41: 275-299.

Klein A (2002) Audit committee, board of director characteristic and earnings management, Journal of Accounting and Economics 33(3): 375-400.

Klein P, Shapiro D and Young J (2005) Corporate governance, family ownership and firm value: the Canadian evidence, Corporate Governance 13(6): 769-784.

Kose J and Lemma W (1998) Corporate governance and board effectiveness, Journal of Banking and Finance 22: 371-403.

La Porta R, López de Silanes F, Shleifer A and Vishny R (1997) Legal determinants of external finance, Journal of Finance 52: 1131-1150.

La Porta R, López de Silanes F, Shleifer A and Vishny R. (1998) Law and finance, Journal of Political Economy 106: 1113-1155.

La Porta R, López de Silanes F, Shleifer A and Vishny $\mathrm{R}$ (2000) Investor protection and corporate governance, Journal of Financial Economics 58: 3-27.

La Porta R, López de Silanes F and Shleifer A (1999) Corporate ownership around the world, Journal of Finance LIV (2): 471-479.

Lane S, Astrachan J, Keyt A and McMillan K (2006) Guidelines for family business boards of directors, Family Business Review 19(2): 147-167.

Le Breton-Miller I and Miller D (2006) Why do some businesses out-compete? Governance, long-term orientations, and sustainable capability?, Entrepreneurship: Theory and Practice (Nov): 731-746.

Lester RK and Cannella AA (2006) Interorganizational familiness: how family firms use interlocking 
directorates to build community-level social capital, Entrepreneurship: Theory and Practice 30: 755-775.

Macey, J. and O'Hara, M. (2003) The corporate Governance of Banks, FRBNY. Economic Policy Review, 9(1): 91-107.

Martin de Holan P and Sanz L (2006) Protected by the family? How closely held family protect minority shareholders, Journal of Business Research 59: 356-359.

Maury B (2005) Family ownership and firm performance: empirical evidence from western European corporations, Journal of Corporate Finance 12: 321-341.

Morck R and Yeung B (2003) Agency problems in large family groups, Entrepreneurship: Theory and Practice 27: 367-382.

Prowse, S.D. (1997) Corporate control in commercial banks. Journal of Financial Research, XX(4): 509-527.

Ricart JE, Álvarez JL and Gallo MA (1999) Governance mechanisms for effective leadership: the case of Spain, Corporate Governance 7(3): 266-287.

Rosenstein S and Wyatt JG (1990) Outside directors, board independence and shareholder wealth, Journal of Financial Economics 26: 175-191.

Sacristán M and Gómez Ansón S (2006) Family ownership, corporate governance and firm value, in Pannikkos Z, Smyrnios KX and Klein S (eds) Handbook of Research on Family Business, pp. 593-613, Edward Elgar, Cheltenham.

Sacristán M and Gómez Ansón S (2007) Family ownership and pyramids in the Spanish market, Family Business Review 20(3): 247-265.
Schulze W, Lubatkin MH, Dino RN and Buchhaltz AK (2001) Agency relationships in family firms: Theory and evidence, Organization Science 12(2): 99-116.

Shivdasani A and Yermack D (1999) CEO involvement in the selection of new board members: an empirical analysis, Journal of Finance 54 (5): 1829-1853.

Shleifer A and Vishny RW (1997) A survey of corporate governance, Journal of Finance 52: 737-83.

Sraer D and Thersmar D (2004) Performance and behaviour of family firms: evidence from the French stock market. WP Centre de Reserche en Economie et Statistique, Tolouse, France.

Stoney, C. and Winstanley, D. (2001) Stakeholding: confusion or utopia? Mapping the conceptual terrain. Journal of Management Studies, 38(5): 602-626.

Sundaramurthy C and Lewis M (2003) Control and Collaboration paradoxes of governance, Academy of Management Review 28(3): 397-415.

Villalonga B and Amit R (2006) How do family ownership, control and management affect firm value?, Journal of Financial Economics 80(2): 385-417.

Voordeckers, W., Van Gils, A. and Van den Heuvel, J. (2007) Board composition in small and medium sized family firms. Journal of Small Business Management, 45: 137-156.

Yermack D (1996) Higher market valuation of companies with a small board of directors, Journal of Financial Economics 40: 185-211.

\section{O R P O RATE ETHICS TRA I N E R \\ THREE DIMENSIONAL ETHICS PERSONAL * CORPORATE * SOCIAL \\ by Attracta Lagan (KMPG) and Brian Moran (Managing Values) ISBN 978-0-9757422-3-5 viii + 176 s/c 2006 \\ 'You have in your hands an important tool for raising ethics awareness and new organisational standards to meet rapidly mutating social requirements.' \\ John Elkington (Author: Cannibals with Forks: The Triple Bottom Line of 21st Century Business)

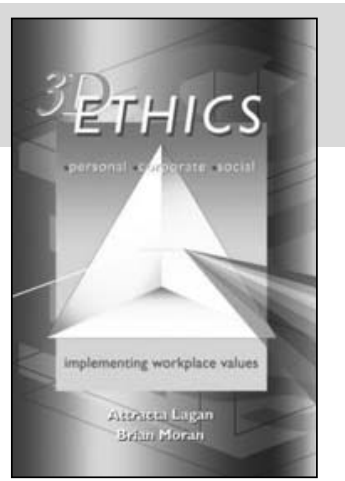 \\ eContent Management Pty Ltd, PO Box 1027, Maleny QLD 4552, Australia \\ Tel.: +61-7-5435-2900; Fax.+61-7-5435-2911; subscriptions@e-contentmanagement.com \\ www.e-contentmanagement.com}

